\title{
Arazi idaresi temel modeli planlama paketi geliştirilmesi için Türkiye mekânsal planlama sisteminin incelenmesi
}

\author{
Okan Yılmaz ${ }^{1}$ (D), Mehmet Alkan ${ }^{1 *}$ (iD \\ ${ }^{1}$ Yıldız Teknik Üniversitesi, Davutpaşa Kampüsü, Inşaat Fakültesi, Harita Mühendisliği Bölümü, Esenler, Istanbul, Türkiye.
}

Öz: Mekânsal planlar birçok sektörel politikanın değerlendirilmesi sonucu ortaya çıkan, sürdürülebilir kalkınmayı sağlamayı amaçlayan, arazi kullanım ve yapılaşma kararları içeren planlardır. Mekânsal plan kararları, özel şahıs mülkiyetinde bulunan taşınmazlara ve ortak kullanım niteliğindeki alanlara yapılaşma ve kullanma yönünden birçok hak, kısıtlılık ve sorumluluk (HKS) getirmektedir. Arazi İdaresi Temel Modeli (AITM), ISO tarafindan yayımlanan bir standarttır ve arazi yönetiminde araziyi etkileyen HKS'ler ve bunların geometrik bileşenleri ile ilgilenir. Standart bir kavramsal model ve ortak ontoloji sunmayı amaçlamaktadır. Arsa ve arazi kullanım kararları üzerinde etki oluşturan birçok faktör bulunmaktadır. Çeşitli faktörler bulunmasına răgmen, araziyi etkileyen HKS'ler modelde temsil edilirken genellikle ülkelerin tapu ve kadastro sistemlerinden faydalanılmakta, çok sayıda HKS içeren diğer olgular dikkate alınmamaktadır. Tapu ve kadastro sistemi dişında mülkiyet üzerinde HKS oluşturan; vergilendirme işlemleri, çeşitli sözleşmeler, yasal belgeler ve mekânsal planlar bulunmaktadır. Çalıșma kapsamında, çok çeșitli HKS'ler içerdiği ve arazi idaresi ile kuvvetli bir ilișkisi olduğundan dolayı mekânsal planlar incelenmiştir. Çalı̧̧ma neticesinde, Türkiye AİTM ülke profiline entegre edilmek amacryla mekânsal planlama paketi oluşturulmasına altlık oluşturacak çıktılar elde edilmesi hedeflenmiştir. Bu doğrultuda yasal altlıklar, örnek mekânsal planlar, plan notları ve yönergeler incelenerek mekânsal planlar sınıflandırılmış, özellikleri belirlenmiş ve temsil ettiği bilgiler elde edilmiştir. Bulgular değerlendirildiğinde AITTM içerisinde mekânsal planlama paketi oluşturulması için yeterli altyapı bilgisi sağlandiğı sonucuna varılmıştır.

Anahtar Sözcükler: Arazi idaresi temel modeli, Mekânsal planlama, Arazi yönetimi, Standardizasyon, 3B kadastro

\section{Review of the Turkey spatial planning system for developing the land administration domain model planning package}

\begin{abstract}
Spatial plans include land use and structuring decisions aimed at ensuring sustainable development, which emerge from the evaluation of many sectorial policies. Spatial plans bring many rights, restrictions and responsibilities (RRR) on privately owned lands and public use areas in terms of construction and use. The Land Administration Domain Model (LADM) is a standard published by ISO and deals with RRRs affecting land and their geometric components in land management. It aims to present a standard conceptual model and common ontology. There are many factors that affect the land and land use. Although there are several factors, the countries' land registry and cadastral systems are used while representing the RRRs affecting the land in the model, other facts containing many RRRs are not included. Except land registry and cadastre system, there are taxation procedures, various contract, legal document and spatial plan that create RRRs on property. Within the scope of the study, spatial plans have been examined as they contain a wide variety of RRRs and have a strong relationship with the land administration. This study aims to obtain outputs that will create a spatial planning package to integrate Turkey into the country profile of the LADM. In this direction, the legal bases, sample spatial plans, plan notes and official documents were examined, and the spatial plans were classified, and the information they represented was obtained. The results were analyzed, and it was concluded that sufficient infrastructure information was provided to create a spatial planning package within the LADM.
\end{abstract}

Keywords: Land administration domain model, Spatial planning, Land management, Standardization, 3D cadastre 


\section{Giriş}

Kentsel ve kırsal bölgelerde yerleşim, üretim ve sürdürülebilir kalkınmaya altlık oluşturan arazi, sınırlı bir kaynaktır. Bu kaynağın etkili, verimli ve adil kullanımını sağlamak amacıyla arazinin fiziki özelliklerinin tespiti, üzerindeki hak, kısıtlılık ve sorumlulukların (HKS) tescili, fonksiyonlarının belirlenmesi ve zamansal olarak takip edilmesi süreçlerini içeren arazi yönetimi kavramı ortaya çıkmıştır. Genel olarak, arazi idare sistemleri belirli bir mekânsal birimin (parseller, binalar vs.) HKS'lerini belirli bir zaman aralığında kayıt altına alır ve saklar. Kayıt objeleri ülkelerin hukuk düzenlerine göre değişiklik göstermekle birlikte genelde taraflar hakkında bilgi, araziye ait HKS'ler ve mekânsal nesne ile ilgili coğrafi ve öznitelik bilgilerini içerir (Guo, Ying, Li, Luo, \& van Oosterom, 2011).

20. yüzyıl sonlarında ülkelerin yasal düzenine, arazi kullanım şekline ve insan-toprak ilişkisine göre farklılık gösteren arazi yönetim sistemlerinin birlikte çalışabilirlik üzerinde olumsuz etkisi ve kabul görmüşs standart bir model eksikliği ortaya çıkmıştır. Bu soruna çözüm olması amacıyla 2000'li yılların başında, Uluslararası Haritacılar Birliği (Federation of Surveyors, FIG) kongrelerinde ve çalışma gruplarında ele alınan arazi yönetim modellerinin standartlaştırılması çalışmalarının ilk çıktısı Kadastro Çekirdek Temel Modeli (Core Cadastre Domain Model, CCDM) olmuştur. İlerleyen yıllarda model güncellenerek Arazi İdaresi Temel Modeli (AİTM) adını almıştır ve 2012 yılında ISO tarafından standart haline getirilmiştir.

AİTM, arazi idaresinin temel bilgilerle ilgili bileşenlerini kapsayan bir referans modeli tanımlar. Bu temel bileşenler Şekil 1'de ana hatları ile temsil edilen 5 sınıfta ele alınabilir. Bunlar; 1. Taraflar (kişiler ve kuruluşlar), 2. HKS, 3. Mekânsal birimler (parseller, binalar ve altyapı ağları), 4. Konumsal kaynaklar (ölçümler), 5. Konumsal temsillerdir (geometri ve topoloji) (Uitermark, van Oosterom, Zevenbergen, \& Lemmen, 2010). Referans modelinin tanımlanmasında AİTM'nin iki temel hedefi bulunmaktadır; bunlardan ilki kendi arazi yönetim sistemlerini oluşturacak ülkelere bir temel standart sunmaktır, diğeri ise farklı ülkelerde tarafların birlikte çalışabilirliğinin sağlanması için ortak bir ontoloji oluşturmaktır. Oluşturulan ortak terminoloji, farklı yargı bölgelerinde uygulamaların ve prosedürlerin ortak tanımına izin verir.

ISO standartlarının belirli periyotlarda gözden geçirilmesi ve gereksinimlere göre yenilenmesi kapsamında günümüzde AITTM'nin yeniden şekillendirilmesi üzerine çalışmalar yapılmaktadır. Çalışma grupları tarafindan yürütülen çalışmalarda AİTM'nin 2.versiyonunu geliştirmek amacıyla; değerleme ve vergilendirme, mekânsal planlama, ülke profili oluşturma metodolojisi geliştirme ve IndoorGML-AİTM kombinasyonu alanlarında çalışmalar yapılarak modelin kapsamı ve uygulama alanları genişletilmeye çalışılmaktadır (Alattas vd., 2017; Çağdaş vd., 2016; Indrajit, van Loenen, Ploeger, \& van Oosterom, 2020a; Kalogianni vd., 2021).

CityGML gibi 3 boyutlu (3B) fiziki şehir modelleri; binalar, zemin yüzeyi, sokaklar ve bitki örtüsü dahil olmak üzere 3B kentsel nesneleri görselleştirirken yasal nesnelerin modellenmesine odaklanmazlar. AİTM gibi kadastro veri modelleri ise; 3B mülkiyet hakları, kısıtlamaları ve sorumlulukları dahil olmak üzere 3B arazi ve mülk sahipliği çıkarlarını yönetir ve sürdürürler (Aien, Rajabifard, Kalantari, \& Shojaei, 2015). Halihazırda AİTM, hak sahipleri ile onların mülkleri arasındaki yasal ilişkilerin yapılandırılmasına yönelik uluslararası kabul görmüş ve standart temelli bir yaklaşım sunmaktadır. AİTM, mevcut arazi yönetim sistemlerinde yasal bilgileri yönetmek için resmi bir veri yapısı sağlar (Atazadeh, Rajabifard, \& Kalantari, 2018). Fiziksel model standartlarından farklı olarak AİTM tescil nesnelerinin yasal HKS sınırlarını belirlemektedir. Yasal kadastro modelleri aracılığı ile nesnelerin yer altından belirli bir yüksekliğe kadar olan karmaşık HKS'leri 3B dijital haritalar olarak sunulabilmektedir. Bu doğrultuda gerçekleştirilen çalışmalardan olan Çin'in Shenzhen şehrinde Guo vd. $(2013,2014)$ tarafından yapılan çalışmalarda 3B HKS alanlarını yönetmek için gerçek bir 3B dijital kadastro sistemi 
uygulanmıştır. Bu uygulama, yapılaşmış çevrede 3B yasal alanların bir temsilini sağlamıştır. Uygulama sayesinde, karmaşık yapılaşma ağlarına sahip şehirlerde, 3B yasal alanların açık ve net bir şekilde temsil edilebileceği saptanmıştır.

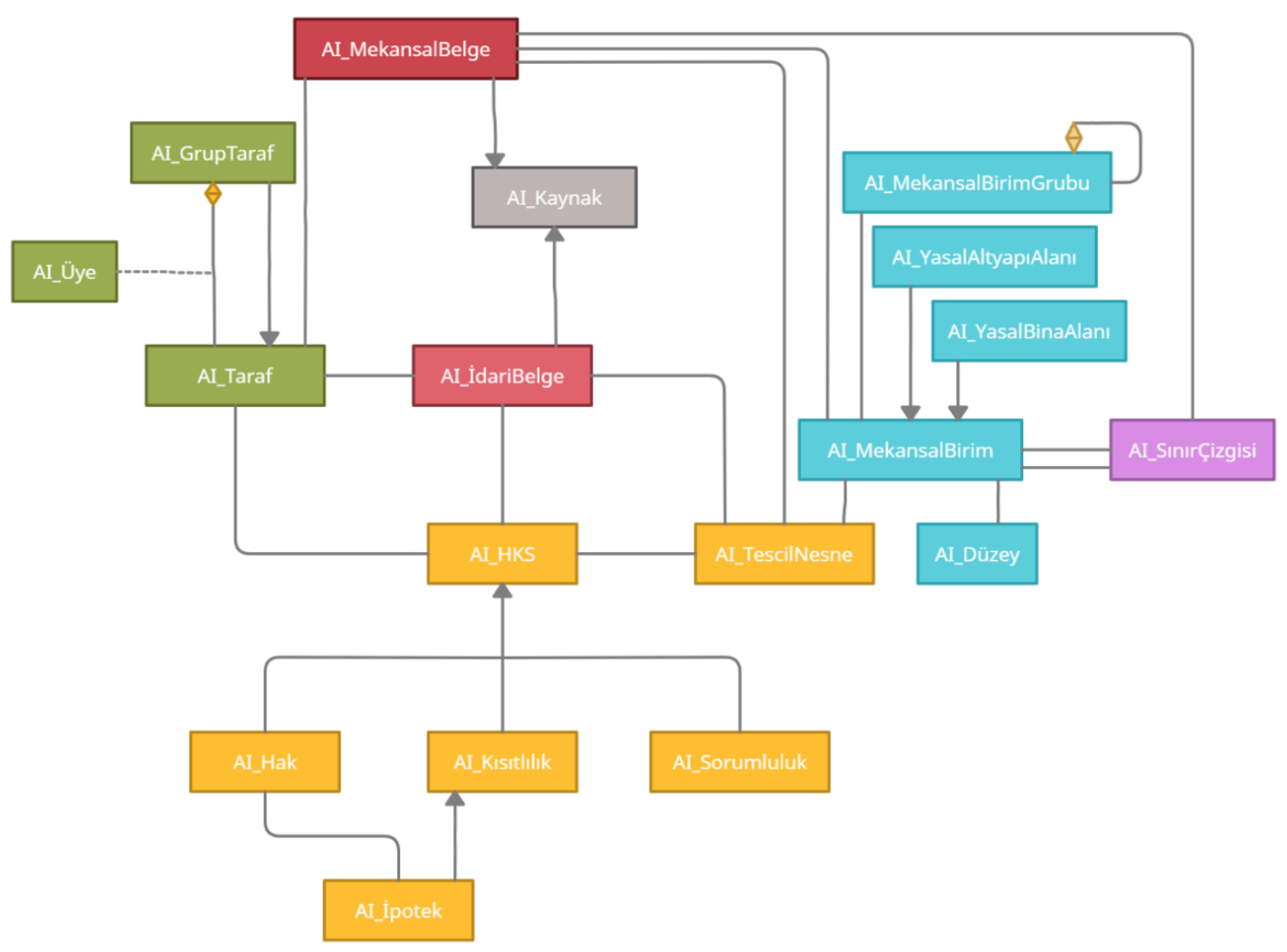

Şekil 1: AiTM ana sınıfları

Arazi idaresi kapsamındaki tescil nesnelerinin 3B olarak kayıt altına alınması, tescil nesnelerinin HKS'lerinin yükseklik ve zaman yönleri dikkate alınarak tespit edilmesi ve 3B kadastro ile bina bilgi modelleme entegrasyonu çalışmalarının önem kazandığı günümüzde; AİTM kapsamında araziyi etkileyen HKS'lerin tam olarak yansıtılıp yansıtılmadığı tartışma konusu olmuştur. Bu doğrultuda arazide fark yaratan her HKS'nin tespit edilip standartlaştırılması çalışmalarına yoğunlaşılmıştır (Indrajit vd., 2020a, 2020b; Lemmen vd., 2019; Paasch, van Oosterom, Lemmen, \& Paulsson, 2015). Mevcutta arazi idaresi temel modeli yargı bölgelerine göre farklılık göstermekle birlikte, ağırlıklı olarak ülkelerin arazi tescil ve tespit (tapukadastro) sistemlerinde bulunan ipotek, irtifak, geçit hakkı gibi hak ve kısıtlamaları temsil etmektedir. Tapu sicilinde bulunan bu HKS'ler dışında çeşitli sözleşmeler, belediye meclis kararları, gayrimenkul değerleme işlemleri ve mekânsal planlar arazi üzerinde HKS'lere yol açmaktadır (Indrajit vd., 2020a). Bu belgelerden en kapsamlısı, etkisi ve çeşitliliği göz önüne alındığında, mekânsal planlardır. Mekânsal planlar farklı ölçeklerde, kapsamlarda ve amaçlarla oluşturulabilmektedir. Planlar oluşturulurken bölgenin ihtiyaçlarını tespit etmek ve bölgeye uygun planı üretmek için bölgenin topoğrafyası, sosyal ve ekonomik yapısı gibi birçok başlıkta çalışmalar yapılmaktadır. Farklı meslek grupları ve kurumlar bir araya gelerek görüş bildirmekte, bölgede yaşayan kişilerin ve sivil toplum kuruluşlarının da anket vb. yollarla fikirlerine başvurulmaktadır. Tüm bu çalışmalar sonucu elde edilen veri kümesi ile bölgede arazi kullanımı, yapılaşma ve günlük hayatı etkileyen birçok karar ortaya çıkmaktadır. Bu kararlar plan paftaları veya plan notları ile sunulmaktadır. Ülkelerin imar ve şehircilik anlayışına göre planların gösterimi, kapsamı ve getirdiği HKS’ler değişiklik göstermektedir. Ülkemizde yürürlükte olan kanun ve yönetmelikler ile arazi kullanımı ve yapılaşmada, mekânsal plan kararlarına sadık kalınması sağlanmaya çalışılmıştır. Mekânsal planların arazi yönetimi ile etkileşimi incelendiğinde; planlar inşa edilecek yapıların alanı, kat sayısı, niteliği gibi yapılaşma haklarının yanında çevre ve doğaya karşı sorumluluklar ve kısıtlılıklar da içerir. Planlar aracılığı ile plan bölgesinde 
sanayi, konut ve ticaret alanlarının yerleri belirlenerek bu alanlarda farklı fonksiyonlarda yapılaşmanın önüne geçilir. Yapılaşma fonksiyonlarının dışında eğitim, sağlık ve sosyal hizmet alanları belirlenerek bu alanlardaki özel mülkiyeti sınırlar ve söz konusu araziler için kurum ve maliklere sorumluluk yükler. Ayrıca mekânsal planlar aracılığıyla afet tehlikeli alanlar, turizm hareketliliği olan alanlar ve sit alanları da belirlenip bu alanları ilgilendiren kararlar alınabilir. Alınan tüm bu kararlar, taşınmazlar üzerine HKS olarak dönmektedir ve kullanımlarını etkilemektedir.

Şehirlerin dijital ikizlerinin oluşturulması, 3B kadastro ve akıllı şehir çalışmaları kapsamında fiziksel modeller ile yasal modellerin entegrasyonu zorunlu bir süreç olarak ortaya çıkmıştır (Alattas, Kalogianni, Alzahrani, Zlatanova, \& van Oosterom, 2021; Atazadeh, Kalantari, Rajabifard, Ho, \& Ngo, 2017; Rajabifard vd., 2019). Bu bağlamda yasal modellerin kapsamını oluşturan tüm HKS'lerin tespiti gerçek durumun temsili için önemlidir. AİTM'nin baz aldığı, ülkelerin tescil ve tespit sistemlerinden gelen bilgiler mülkiyet üzerinde oluşan her HKS'nin temsili için yetersizdir. Özellikle 3. boyutun önem ifade ettiği çalışmalar için 3. boyutta birçok HKS barındıran mekânsal planlar, iyi bir kaynak oluşturmaktadır.

Mekânsal planlar ve arazi idaresi arasında birbirlerini tamamlayan bir ilişki bulunmaktadır. Sağlıklı işleyen bir arazi yönetim sistemi için planlama verileri ile taşınmazların yasal ve fiziki durumunu gösteren veriler entegre olmalıdır. Cheng, Turkstra, Peng, Du ve Ho (2006) çalışmalarında, Sosyalizm ve Açık Kapı (Open Door) politikaları sonrası Çin'de meydana gelen şehirleşme hareketlerini incelemiş; bu kapsamda arazi idaresi ve planlama verilerinin aynı formatta olmaması, ayrı birimlerde saklanması ve birbiriyle uyumsuz olması sonucu şehirleşmenin olumsuz etkilendiği sonucunu çıkarmışlardır. Ayrıca çalışmada şehir plancılarının bu koordinasyon eksikliğinden dolayı yaşadığı zorluklardan bahsedilerek çözüm önerileri sıralanmıştır. Aien vd. (2015) çalışmalarında 3B kadastro yönünden yasal ve fiziksel modelleri incelemişlerdir. Çalışma, nüfus artışı ve şehirleşmenin mekânsal planlama üzerindeki baskısı sonucu komplike mülkiyet yapılarının ortaya çıktığına değinerek, önerilen 3 boyutlu kadastro veri modelinde (3D Cadastral Data Model, 3DCDM) esneklik ve yasal-fiziksel model entegrasyonun sağlanması için arazi idaresi ve mekânsal planlama kavramlarının önemine değinmiştir. Mülkiyet üzerinde HKS oluşturan etmenlerin kadastro sistemine entegrasyonu alanında bir diğer çalışma ise Kadastro 2014 vizyonu çerçevesinde İsviçre'de gerçekleştirilen kamu hukuku kısıtlamaları (Public-law restrictions, PLR) kadastrosu çalışmasıdır. PLR kadastrosu fikri arazi parçaları hakkında açıkça anlaşılır ve yasal olarak bağlayııı bilgilere kolay erişime izin veren bir araç olma iddiası ile ortaya çıkmıştır. Bu çalışma doğrultusunda yapılan ilk incelemede, 150 adet PLR türü tespit edilmiştir. Bu türler arasında imar planları kısıtlamaları, yer altı suyu koruma sorumlulukları, havaalanları için koruma alanları ve kirlilik ile ilgili sınırlamalar bulunmaktadır. Tespit edilen PLR türlerinden her biri için bir veri modeli üzerinde standartlaştırma çalışmaları yapılmaktadır. 2020'li yıllarda bütün İsviçre kanton bölgelerinde tamamlanacağı düşünülen çalışmalar ile İsviçre, arazi mülkiyeti üzerindeki kamu hukuku kısıtlamalarının sistematik olarak belgeleneceği ve merkezi olarak yayımlanacağı bir kadastro geliştiren dünyadaki ilk ülkelerden biri olacaktır (SFOTS, 2015; Steudler, 2014).

Sürdürülebilir kalkınmanın tesisi için mekânsal planlamada elde edilen bilgiler arazi idaresini etkileyecektir ve bunun tersi de geçerlidir. Bu nedenle, hem mekânsal planlamanın hem de arazi yönetiminin arazi kullanımını etkileyen her yönü yasal olarak bağlayıcı kurallar içerdiğinden tanımlanmalı, belgelenmeli ve standartlaştırılmalıdır (Indrajit vd., 2020a). Ülkelerin arazi yönetim sistemlerine mekânsal planları dahil etmesi arazi ve insan arasında daha güçlü ve sağlıklı bir ilişki sağlayacak, bütüncül bir arazi yönetimi yaklaşımı ortaya çıkaracaktır. Ayrıca planlar yatırım yapacak iş insanları ve vatandaşlar için de yatırımları yönlendirecek birçok faktör içerdiğinden, yer seçimi ve ruhsat işlemleri için belirleyici olmaktadır.

Mekânsal planların arazi yönetim sistemlerine dahil edilmesi ile ilgili çalışmalar incelendiğinde; söz konusu çalışmalarda, içerdiği çeşitli imar ve kullanım kararları ile parseller üzerinde birçok HKS oluşturduğundan ve kapsadığı alanların sınırlarını net olarak sunduğundan dolayı imar plan kararlarının kullanımının tercih edildiği görülmektedir (Bydłosz, Bieda, \& Parzych, 
2018; Indrajit vd., 2020a). Arazi yönetim sistemlerinin farklı ülkelerde farklılık gösterdiği gibi planlama kademeleri ve uygulama şekli de ülkelere göre farklılık göstermektedir. Planlama verilerinin modellenmesi ve arazi yönetim sistemine entegrasyonu noktasında Polonya ve Endonezya özelinde çalışmalar yapılmıştır. Bydłosz vd. (2018) 3B Polonya kadastro UML modeli içerisinde planlama bilgilerini içerecek sınıflar oluşturmuştur ve bu sınıfların mevcut kadastro modeli ile ilişkisini ortaya koymuştur. Indrajit vd. (2020a) ISO 19152 AİTM içerisinde bir planlama paketi oluşturulmasını önermişlerdir. Önerilen paket 3 sınıf içermektedir, bu sınıflar ile plan içerikleri ve planlar arasındaki hiyerarşi temsil edilmektedir. Ayrıca çalışmada mekânsal planların AİTM içerisine entegrasyonu için en optimum çözümün yeni bir paket olarak eklenmesi olacağı, böylece AİTM sınıflarının tekrar tekrar kullanılmasının önüne geçilebileceği sonucuna varılmıştır. Yine Indrajit vd. (2021) yaptıkları çalışmada önceki çalışmada oluşturulan mekânsal planlama paketini Endonezya AİTM ülke profiline entegre etmiş ve online ruhsat başvuru ve onayı sistem temsilinde kullanarak etkinliğini göstermiştir.

2010 yılı itibari ile dünyadaki gelişmeler ışığında Türkiye'de de AİTM alanında akademik çalışmalar hız kazanmıştır. İnan (2010) doktora tezinde arazi idaresi açısından ülkedeki tarımsal yapılaşmaya değinerek AİTM ile uyumlu bir konumsal veri modeli geliştirmiştir. Döner (2010) "Türk Kadastro Sistemine Üç Boyutlu Yaklaşım" başlıklı doktora tezinde, AİTM'nin 3B kadastro desteğini incelemiştir. İnan ve Yomralığlu (2011) çalışmalarında AİTM'yi incelemişler ve Türkiye arazi yönetim sistemi için mekânsal modelleme önermişlerdir. Çete ve İnan (2013) çalışmalarında AİTM'yi ele alarak Türkiye kadastrosunun önemine değinmişlerdir. Aydınoğlu ve İnan (2014) tapu ve kadastro bazlı bir veri modeli geliştirmiş ve modeli Tapu Kadastro Bilgi Sistemi (TAKBİS) ve Türkiye Ulusal Coğrafi Bilgi Sistemi (TUCBS) projeleriyle ilişkilendirmişlerdir. Çağdaş vd. (2016) çalışmalarında AİTM'ye dayalı bir değerleme ve vergilendirme veri modeli geliştirmiştir. Alkan ve Polat (2017, 2018) çalışmalarında Türkiye için temel sınıflarla ilgili bir AİTM modeli önermişlerdir. Polat, Alkan ve Lemmen (2020) ise çalışmalarında AİTM kapsamında Türkiye kadastro sisteminde HKS’lerin zamansal temsilini incelemişlerdir. Gürsoy Sürmeneli ve Alkan (2020) çalışmalarında uluslararası standartları inceleyerek 3B kadastro ülke profili tasarlamışlardır. Ülkemizde yapılan bu çalışmalar incelendiğinde, 3B kadastroya yönelik çalışmalar yapıldığı fakat plan verilerinin ülke profiline entegre edilmesine yönelik henüz bir çalışma yapılmadığı görülmektedir. Söz konusu çalışma, nihayetinde literatürdeki bu boşluğu tamamlamayı amaçlamaktadır.

Önceki bölümlerde bahsedildiği gibi AİTM, mekânsal planlama verilerini modele dahil etmemektedir ve standartlaştırmamaktadır. Ancak model, ana sınıflarda yer verilmeyen veri kümeleri için, diğer standartlarda belirtildiği doğrultuda bilgi modellerine dayalı olarak AİTM'nin harici kaynaklardan beklediği veri kümesi öğelerini sağlar (Lemmen, van Oosterom, Uitermark, Zevenbergen, \& Cooper, 2011). Harici sınıflar yardımı ile AİTM ana sınıflarına yeni paketler ilave edilebilir. Böylece arazi yönetim modellerindeki eksiklikler tamamlanabilmekte ve model, gereksinimlere göre modernize edilebilmektedir.

Bu çalışmada AİTM Türkiye ülke profiline entegre planlama paketi oluşturulması maksadıyla; Türkiye mekânsal plan hiyerarşisi, plan kademeleri, plan özellikleri, planlama yetkisi bulunan kurumlar ve planların getirdiği HKS'ler incelenmiştir. Taşınmazlar üzerinde HKS oluşturan birçok faktör olmasına karşın çalışmanın kapsamı mekânsal planlar ve planların içerdiği HKS'ler olarak belirlenmiştir. Çalışmanın bulgularının oluşturulacak mekânsal planlama paketinin sınıfları, öznitelikleri ve bunların arasındaki ilişkiye altlık oluşturacağı düşünülmüştür. Çalışmanın 2. kısımda izlenen yol, yöntem, incelenen planlar ve tablolar açıklanmıştır; 3.bölümde elde edilen bulgulara değinilmiştir ve son bölümde sonuçlara ve önerilere yer verilmiştir. 


\section{Metodoloji}

Planların genel özelliklerini, aralarındaki hiyerarşiyi, kapsamını ve içerdiği bilgileri tespit etmek amacıyla Şekil 2'de sunulan iş akış düzeni izlenmiş̧ir. Veri toplama ve dokümanların analizi noktasında değişkenler arasındaki ilişkilerin varlığını inceleyen ve bir nicel araştırma yöntemi olan bağıntısal yöntem benimsenmiştir. Böylece farklı kademelerde yer alan plan verileri karşılaştırılmış, benzerlik ve farklılıkları ortaya konmuştur. Mekânsal planların yasal dayanakları, kapsamları ve planlamada yetkili kurumların belirlenmesi amacıyla, ilk olarak planlara dayanak oluşturan kanunlar ve yönetmelikler incelenmiştir. Normlar hiyerarşisi kavramı gözetildiğinde; anayasanın kanunlardan, kanunların ise yönetmelikten öncelikli olduğu görülmektedir. Anayasanın en üstün yasal belge olmasından hareketle, planlama faaliyetlerinin 1982 Türkiye Cumhuriyeti Anayasasının 166. maddesinden temel aldığı görülmektedir. Bu madde şu şekildedir: "Ekonomik, sosyal ve kültürel kalkınmayı, özellikle sanayinin ve tarımın yurt düzeyinde dengeli ve uyumlu biçimde hızla gelişmesini, ülke kaynaklarının döküm ve değerlendirilmesini yaparak verimli şekilde kullanılmasını planlamak, bu amaçla gerekli teşkilatı kurmak Devletin görevidir.” (Türkiye Cumhuriyeti Anayasası, Md.166). Anayasa'da belirtilen bu görevin yerine getirilmesi ve yerleşme yerleri ile bu yerlerdeki yapılaşmaların; plan, fen, sağlık ve çevre şartlarına uygun teşekkülünü sağlamak amacıyla 3194 sayılı İmar Kanunu 1985 yılında yürürlüğe girmiştir. Bu kanun, imar uygulamaları yönünden kendisinden sonra çıkarılacak yönetmeliklere yol gösterici niteliktedir. Kanun mekânsal planların tanımı, kapsamı, hiyerarşisi, alt-üst kademe plan ilişkisi, taşıması gereken nitelikler ve uygulamaları hakkında kararlar içermektedir. Bunun dışında kanunda; planları yapma, denetleme ve onaylama yetkisi olan yerel idareler ile T.C. Çevre, Şehircilik ve İklim Değişikliği Bakanlığı'nın (ÇŞB) görevleri, planların uygulama şekilleri, plan askı süreleri ve planlar arasındaki ilişki sunulmuştur. Ayrıca kanunda arsa arazi düzenlemesi uygulamalarına ve yapılaşmaya ilişkin düzenleyici maddelere yer verilmiş̧ir.

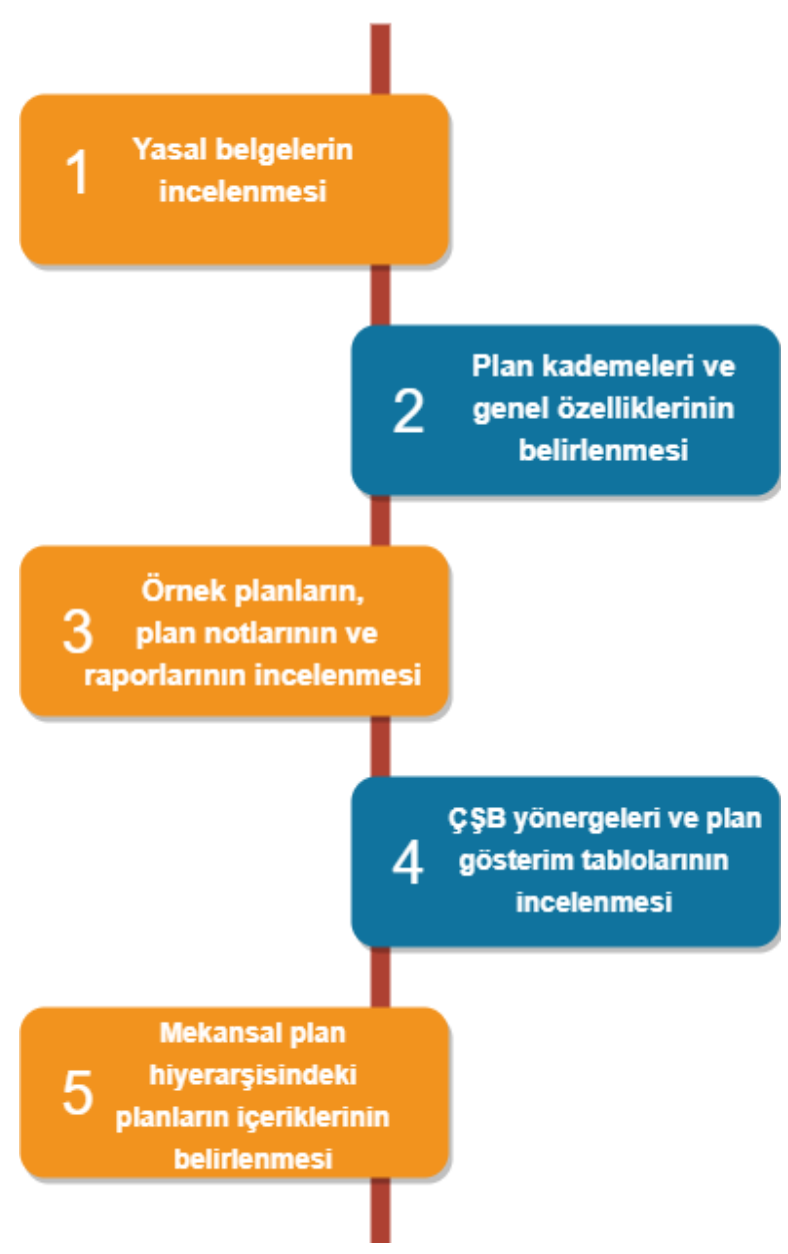

Şekil 2: Çalışma iş akış şeması 
İmar kanunu dayanak alınarak arazi kullanım ve yapılaşma kararları getiren mekânsal planların yapım ilkelerini belirlemek amacıyla, Mekânsal Planlar Yapım Yönetmeliği (MPYY) yayımlanmıştır. Bu yönetmelik; fiziki, doğal, tarihi, kültürel değerleri korumak ve geliştirmek, koruma ve kullanma dengesini sağlamak, ülke, bölge ve şehir düzeyinde sürdürülebilir kalkınmayı desteklemek, yaşam kalitesi yüksek, sağlıklı ve güvenli çevreler oluşturmak üzere hazırlanan, arazi kullanım ve yapılaşma kararları getiren mekânsal planların yapımına ve uygulanmasına ilişkin usul ve esasları belirlemek amacıyla yürürlüğe konmuştur (MPYY, Md.1). Bu yönetmelik ile her türde ve ölçekte plan projelerine yönelik usuller, esaslar ve izlenecek yollar belirlenmiştir. Yönetmelikte planlar, plan unsurları, plan standartları ve içerikleri açıklanmıştır. Ayrıca yönetmelikte mekânsal planlarda ve plan notlarında ayrıntılı olarak gösterilecek, belediye hizmet alanları ile sosyal, teknik ve kültürel tesis alanları hakkında tanımlamalar verilmiştir. Yönetmelik her kademede plan yapımı için kapsayıcılık gösterdiğinden yönetmelikte; mekânsal strateji planları (MSP), çevre düzeni planları (ÇDP), imar planları ve özel amaçlı planlar ayrı ayrı ele alınarak taşıması gereken nitelikler açıklanmıştır. Planların dışında kentin siluetine ve ihtiyaçlarına uygun yapıların oluşturulmasına yönelik projeler olan kentsel tasarım projelerine yönelik kararlar da yönetmelikte yer almaktadır.

Planlama ve imar ile doğrudan ilişkili diğer yasal belgeler ise plan bulunan alanlarda fen, sağlık ve sürdürülebilir çevre şartlarına uygun yapı ve yapılaşma ile projelendirmeye ve denetime ilişkin usul ve esasları belirleyen Planlı Alanlar İmar Yönetmeliği (PAİY) ile herhangi bir planın bulunmadığı alanlarda yapılaşmaların fen, sağlık ve çevre şartlarına uygun teşekkülünü sağlamayı amaçlayan Plansız Alanlar İmar Yönetmeliği’dir. Bu yönetmeliklerde bahsi geçen alanlarda yapılacak yapılara, yapı nizamlarına, yapı fonksiyonlarına, yapıların katlar alanı ve yüksekliğine göre uyulması gereken standartlar, sınırlamalar ve haklar belirtilmiştir. Ayrıca bu yönetmeliklerde yapıları inşa ve kontrol ile sorumlu müteahhit ve fenni mesullerin taşıması gereken şartlara ve yapı ruhsatı ile ilgili düzenlemelere de yer verilmiştir. PAİY'de yer alan diğer bir önemli nokta ise, planlı alanlarda planda belirtilmeyen uygulamaların nasıl yapılacağı ve hangi kısıtlamalara uyulacağının belirtilmesidir.

Bahsedilen kanun ve yönetmeliklerin dışında özel alanlarda, özel amaçlar için hazırlanan planların yapım ve uygulama süreçleri hakkındaki işleyiş, amaç doğrultusunda yürürlüğe giren ilgili yasal belgede ve plan yapmaya yetkili kurumun işleyiş yönetmeliğinde düzenlenmiştir. Türkiye yapılaşma ve planlama faaliyetlerini düzenleyen yasal belgeler Şekil 3'te gösterilmektedir.

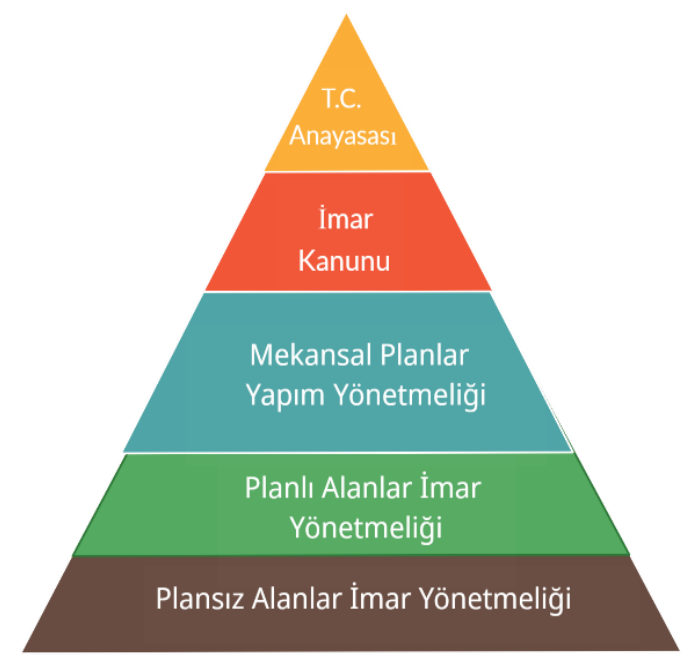

Şekil 3: Yapılaşma ve planlama faaliyetlerini düzenleyen yasal kaynaklar 
Mekânsal planların yasal altlıkları incelendikten sonra planların temsil ettiği varlıkları ve temsil şekillerini incelemek maksadıyla ÇŞB'nin yayımladığı her kademe plan için, ana başlıklar ve alt başlıklar halinde yayımlanan gösterim tabloları ve farklı kademelerdeki planların ortak gösterimlerini içeren gösterim tablosu incelenmiştir. Böylece ilgili düzeydeki planın neleri kapsayabileceği, ne gibi bilgileri içinde barındırabildiği tespit edilmiştir. Gösterim tablolarının incelenmesinin sebebi, var olan her planın sadece plan bölgesinde bulunan alanlar mahiyetinde plan lejantında temsil edilebilmesi, ÇŞB'nin yayımladığı gösterim tablolarının ise kademesine göre planın gösterebileceği tüm detayları içermesidir. Bir başka deyişle ÇŞB gösterim tabloları Büyük Ölçekli Harita ve Harita Bilgileri Üretim Yönetmeliği’nin son kısmında bulunan detay ve öznitelik kataloglarına benzetilebilmektedir. Söz konusu kademedeki planın içerebileceği tüm bilgileri gösterdiğinden dolayı ÇŞB gösterim tabloları incelenerek, planların kapsamının eksiksiz anlaşılması sağlanmıştır. Tablo 1'de nazım imar planı (NIP) için yayımlanan gösterim tablosundan bir kesite yer verilmiştir.

Tablo 1: Mekânsal planların içerdiği bilgi ve gösterimler tablosu (ÇŞB)

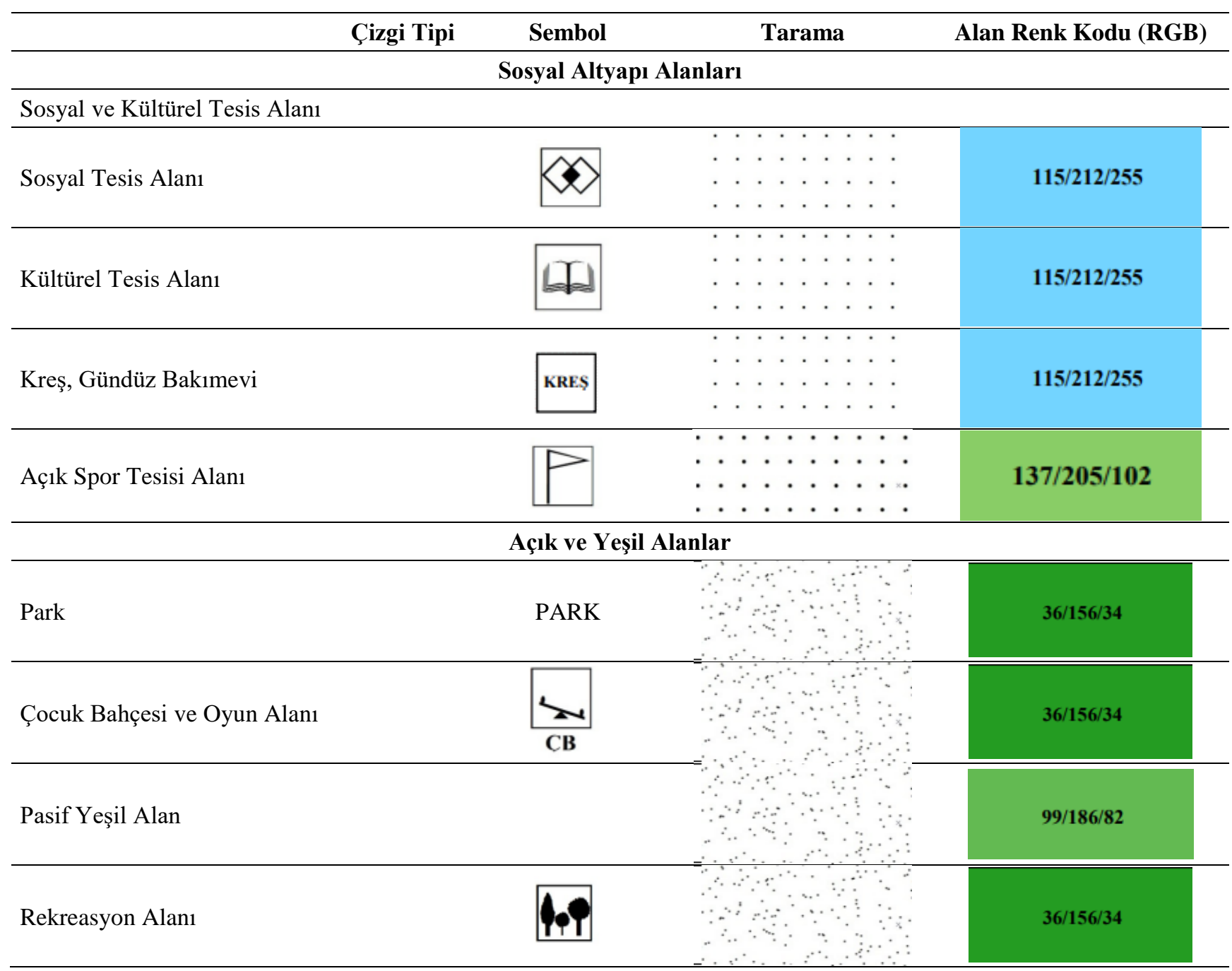

Gösterim tablolarının incelenmesinin akabinde plan notları, lejant ve ayrıntılı raporları ile bir bütün olarak hazırlanan mekânsal planlar incelenmiştir. Plan paftalarının ve planlama işleminin unsurlarından olan plan notlarının, hangi bilgileri içerdiği ve mülkiyet üzerine ne gibi haklar, kısıtlamalar ve sorumluluklar getirdiğini tespit etmek amacıyla gerçek planlar üzerinden bir inceleme yapılmıştır. Bu amaçla 1/100 000 ölçekli Sinop-Kastamonu-Çankırı ÇDP (Şekil 4), 1/5000 ölçekli Hadımköy sanayi bölgesi NIP (Şekil 5a), 1/1000 ölçekli Hadımköy sanayi bölgesi 2. etap uygulama imar planı (Uï) (Şekil 5b) ve bu planların plan notları incelenmiştir. Plan paftalarında lejant yardımı ile ÇŞB gösterim tablosundan yararlanılarak, bölgedeki alanların fonksiyonları ve coğrafi özellikleri temsil edilirken, plan notlarında genel ve özel hükümler altında 
paftada gösterilemeyecek bilgilere ve HKS'lere değinilmektedir. Planlamanın diğer bir unsuru olan plan açıklama raporları; planlama alanın konumu, alana dair bilgiler, kurumların görüşleri, projeksiyonlar ve analizleri içermektedir. Planlamaya altlık oluşturan ve planlama öncesi çalışmaları içeren bu belgeler, çalışmanın sonuçlarını etkilemeyeceği için incelemeye alınmamıştır.

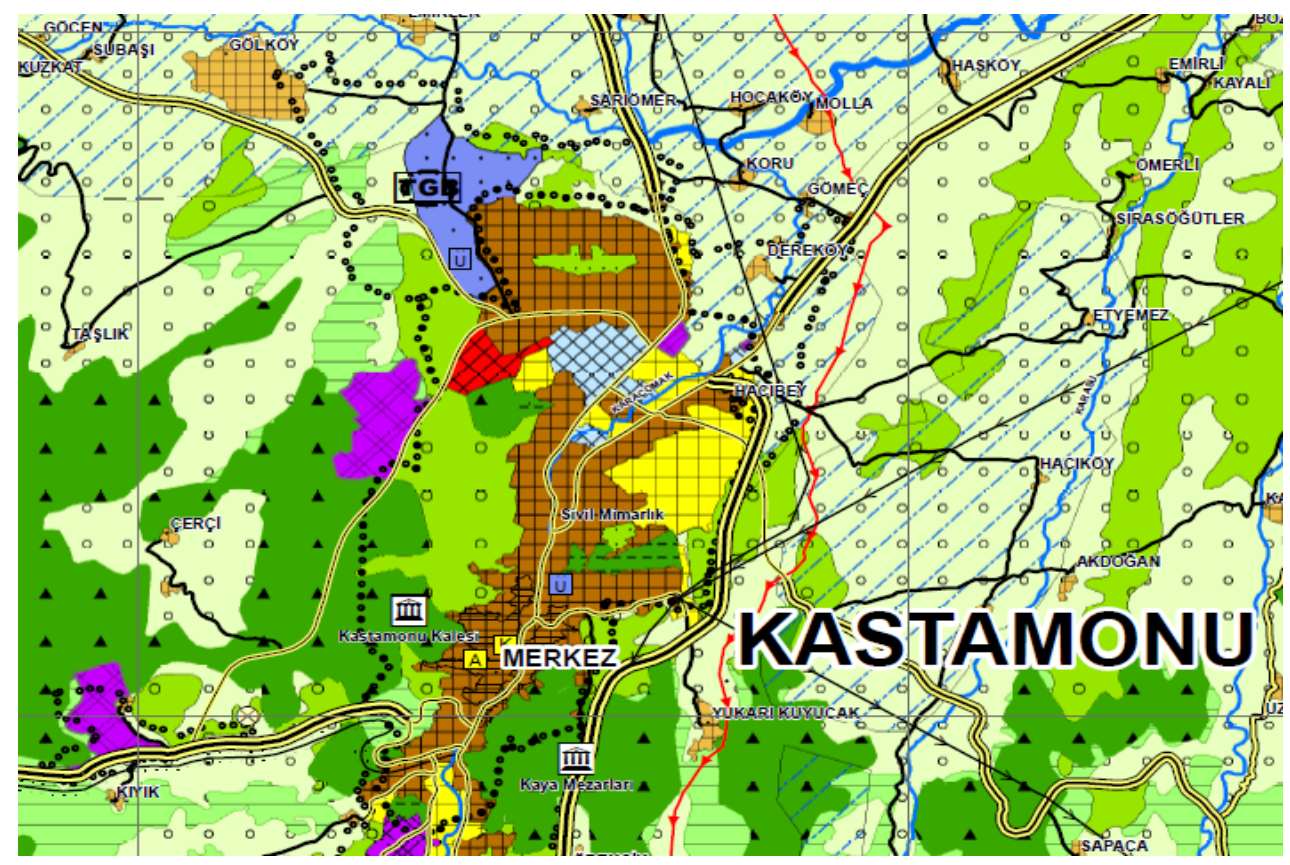

Şekil 4: 1/100 000 ölçekli Sinop-Kastamonu-Çankırı çevre düzeni planından bir kesit (ÇŞB)

Çalışmanın metodolojisi noktasında tanıtılan yasal belgeler ve farklı kademedeki mekânsal planlar, çalışma verisi olarak değerlendirilmiştir. Yasal dayanaklar ele alınarak mekânsal planlama sisteminin özü ve sistematiği anlaşılmış, planlar arasında ilişki kurulmuştur. Örnek planlar, plan notları ve gösterim tabloları incelendiğinde ise nicel araştırma tekniği ile farklı kademelerdeki planların içerdiği bilgiler karşılaştırılmış ve farklar ortaya konmuştur. Materyaller incelenerek AİTM içerisinde mekânsal planlama paketi oluşturulması için hangi özelliklerin belirlenmesi gerektiği tespit edilerek bu veriler elde edilmiştir. Elde edilen özelliklerin neye göre kategorize edilmesi ve nasıl sunulması gerektiğine karar verilerek bulgular kısmında sunulmuştur.
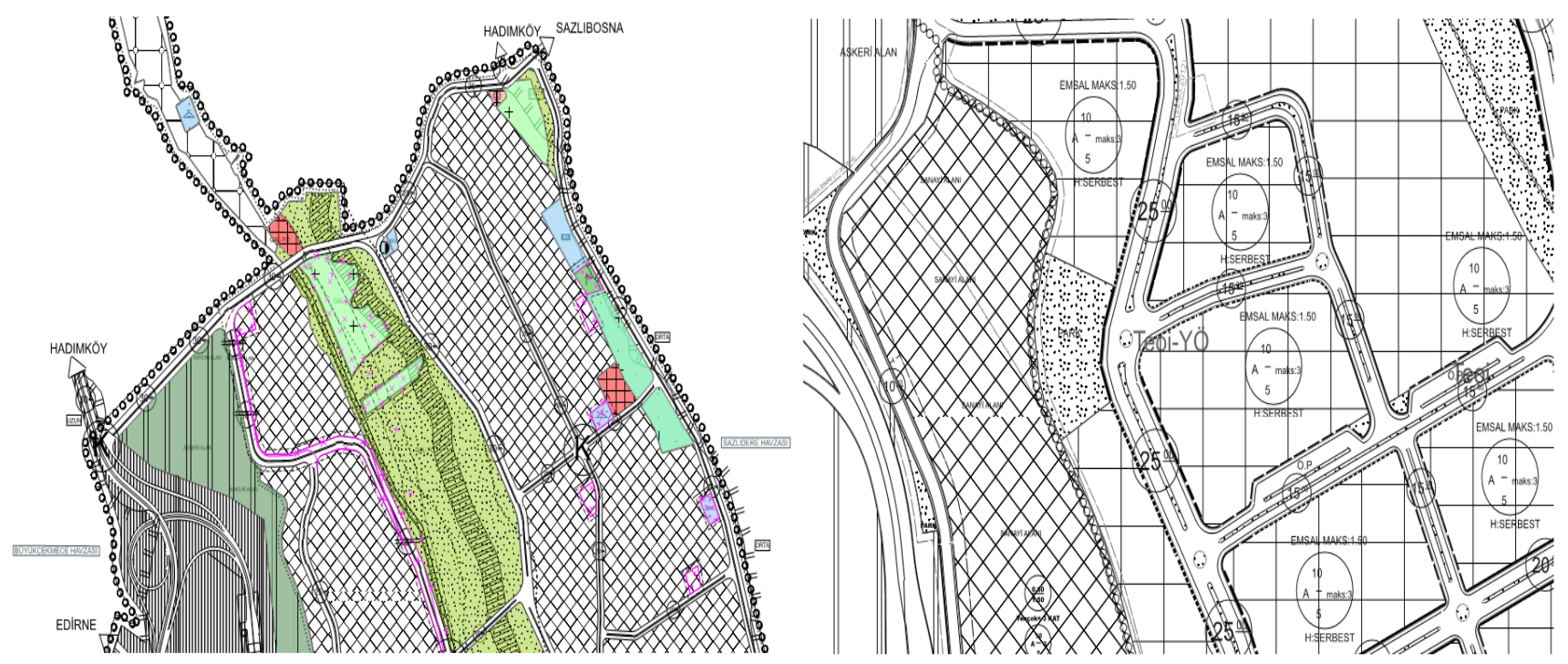

Şekil 5: Hadımköy bölgesine ait NiP (a) ve UiP'den (b) kesitler 


\section{Bulgular}

Kalkınma planlarının emrettiği şekilde varsa bölge planları, bölgesel gelişme stratejileri ve diğer strateji belgelerinde ortaya konulan hedefler dikkate alınarak oluşturulan mekânsal strateji planları ile başlayan, üst kademe planların alt kademe planları yönlendirme ilkesi doğrultusunda en alt seviyede imar planlarının oluşturulması ile son bulan Türkiye mekânsal planlama faaliyetleri işleyişi bu çalışmada ele alınmıştır.

Çalışma neticesinde yasal belgelerden çıkarılan ana planlama hiyerarşisi Şekil 6'da sunulmuştur. Bu hiyerarşiye göre, planlar üst ölçekten alt ölçeğe kademeli bütünlük ilkesi ile tanımlanan yaklaşım doğrultusunda üst kademesinde bulunan plana uygun hazırlanmalı, üst kademe planda meydana gelen değişikliklere göre alt kademe plan bir yıl içerisinde revize edilmelidir. Planlar üst kademeden alt kademeye boşluğa mahal vermeden ilerliyor gibi gözükse de ülkemizde planlama eksikliğinden dolayı her kademe plan her bölgede bulunmamaktadır. Bu sorunun ortaya çıkardığı durum neticesinde mekânsal strateji planı olmayan bölgelerde çevre düzeni planı, çevre düzeni planı bulunmayan bölgelerde ise NİP çalışmaları yapılabilmektedir. Bu duruma istisna olarak sadece NIPP bulunmayan bölgelerde UİP yapılamamaktadır. UİP yapılabilmesi için planlama bölgesinde hazırlanmış bir NİP bulunma şartı vardır. Özel durumlarda bu iki plan birlikte hazırlanabilmektedir. Türkiye’de mekânsal planlama, ana hiyerarşi bakımından belirli kurumların (ÇŞB, il özel idareleri, belediyeler) kontrolünde olsa da özel alanlar için oluşturulan özel amaçlı planların yapımı ve denetimi ile yetkili birçok kurum bulunmaktadır. Bundan dolayı planlama sektörü kendi içerisinde sistematik bir birlikte çalışabilirlik organizasyonuna ihtiyaç duyar. Yetki alanları, plan yapma, onama ve denetleme görevleri net olarak tanımlanmalıdır. Mekânsal planlama misyonunda birçok kurum görev alsa da kurumların yaptığı ve yaptırdı̆̆ı her ölçekte planı denetleme yetkisi, ÇŞB'ye ait olduğundan dolayı bakanlık mekânsal planlamada en yetkili kurum niteliğindedir.

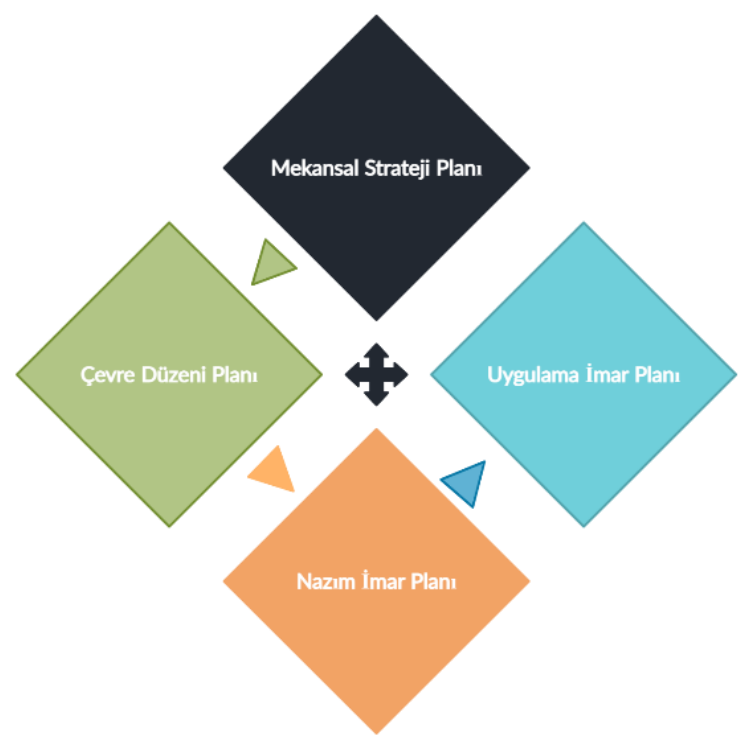

Şekil 6: Ana mekânsal plan hiyerarşisi

Çalışmanın amacı arazi yönetiminde HKS oluşturan planlama etmenlerinin tespiti ve AİTM'de HKS'lerin eksiksiz temsili için planlama paketinin oluşturulmasına altlık oluşturacak çıktıları elde etmekti. Söz konusu çıktılar mekânsal planlama sisteminde halihazırda var olan bilgilerdir. Elde edilen çıktılar var olan bu bilgileri AİTM'ye aktarılabilecek hale getirmek için kullanılacaktır. Mekânsal planlama paketi oluşturulması amacı doğrultusunda öncelikle Türk hukuk sisteminde mekânsal planlama ile ilgili kanun ve yönetmelikler incelenerek çeşitli kademelerdeki planların; yapım yetkisi, denetleme yetkisi, ölçeği, hiyerarşisi ve amacı gibi bilgileri belirlenmiştir (Tablo 2). 
Tablo 2: Ana planlama hiyerarşisinde bulunan planların genel özellikleri

\begin{tabular}{|c|c|c|c|c|}
\hline & Mekansal Strateji Planı & Çevre Düzeni Planı & Nazım İmar Planı & Uygulama İmar planı \\
\hline Yapım Yetkisi & $\begin{array}{l}\text { Çevre ve Şehicilik } \\
\text { Bakanlığ } 1\end{array}$ & $\begin{array}{c}\text { ÇŞB,Büyükşehir } \\
\text { belediyeleri,ı̇l özel } \\
\text { İdaresi }\end{array}$ & $\begin{array}{l}\text { ÇŞB,Belediyeler,İl } \\
\text { özel İdaresi }\end{array}$ & $\begin{array}{c}\text { ÇŞB,Belediyeler,İl özel } \\
\text { İdaresi }\end{array}$ \\
\hline $\begin{array}{l}\text { Denetleme } \\
\text { Yetkisi }\end{array}$ & $\begin{array}{l}\text { Çevre ve Şehicilik } \\
\text { Bakanlığ } 1\end{array}$ & $\begin{array}{c}\text { ÇŞB,İl genel } \\
\text { meclisi,Belediye meclisi }\end{array}$ & $\begin{array}{c}\text { ÇŞB,İl genel } \\
\text { meclisi,Belediye } \\
\text { meclisi } \\
\end{array}$ & $\begin{array}{c}\text { ÇŞB,İl genel } \\
\text { Meclisi,Belediye } \\
\text { Meclisi } \\
\end{array}$ \\
\hline Kapsam & $\begin{array}{l}\text { Ülke bütünü,Karasuları, } \\
\text { Ülke münhasır ekonomi } \\
\text { bölgeleri }\end{array}$ & $\begin{array}{c}\text { Bir veya birden fazla il } \\
\text { sinırları,sosyal,ekonomik } \\
\text { veya idari benzerlik } \\
\text { gösteren bölgeler ve } \\
\text { havzalar }\end{array}$ & $\begin{array}{l}\text { Nüfusu } 10 \text { Bini } \\
\text { geçmiş kentsel ve } \\
\text { kırsal yerleşme } \\
\text { alanları }\end{array}$ & $\begin{array}{c}\text { Yerleşim,Ticaret, } \\
\text { Sanayi alanları, } \\
\text { Koruma bölgeleri, } \\
\text { Sahil şeridi,Afet } \\
\text { tehlikeli alanlar, Islah } \\
\text { bölgeleri ve Turizm } \\
\text { alanları } \\
\end{array}$ \\
\hline Ölçek & $1 / 250.000-1 / 500.000$ & $1 / 50.000-1 / 100.000$ & $1 / 5.000-1 / 25.000$ & $1 / 1.000$ \\
\hline $\begin{array}{c}\text { Plan } \\
\text { Unsurları }\end{array}$ & $\begin{array}{c}\text { Sektörel paftalar,Tematik } \\
\text { paftalar,Plan raporu }\end{array}$ & $\begin{array}{l}\text { Plan, Plan notları, Plan } \\
\text { raporu,Lejant }\end{array}$ & $\begin{array}{c}\text { Plan,Plan } \\
\text { notları,Plan } \\
\text { raporu,Lejant }\end{array}$ & $\begin{array}{l}\text { Plan, Plan notları,Plan } \\
\text { raporu,Lejant }\end{array}$ \\
\hline $\begin{array}{l}\text { Yönlendirici } \\
\text { Belgeler }\end{array}$ & $\begin{array}{c}5 \text { Yıllık Kalkınma } \\
\text { Planları,3194 Sayılı İmar } \\
\text { Kanunu, MPYY }\end{array}$ & $\begin{array}{l}3194 \text { İmar Kanunu } \\
\text {,MPYY,Eşik analizleri, } \\
\text { Kurum görüşleri }\end{array}$ & $\begin{array}{l}3194 \text { İmar Kanunu } \\
\text {,MPYY,PAİY, } \\
\text { Kurum görüşleri }\end{array}$ & $\begin{array}{c}3194 \text { İmar Kanunu } \\
\text {,MPYY,PAİY, kurum } \\
\text { görüşleri }\end{array}$ \\
\hline Amaç & $\begin{array}{l}\text { Doğal,tarihi kültürel } \\
\text { değerlerin korunması,afet } \\
\text { risklerinden korunulması, } \\
\text { kaynak kullanımında } \\
\text { etkinlik,yer altı ve yer üstü } \\
\text { kaynakların ekonomiye } \\
\text { kazandırılmasına,doğal, } \\
\text { tarihi ve kültürel değerlerin } \\
\text { korunmasına ve } \\
\text { geliştirilmesine,yerleşmeler, } \\
\text { ulaşım sistemi ile kentsel, } \\
\text { sosyal ve teknik altyapının } \\
\text { yönlendirilmesine dair } \\
\text { mekânsal stratejileri } \\
\text { belirlemek }\end{array}$ & $\begin{array}{c}\text { Kentsel ve kırsal } \\
\text { yerleşim, gelişme } \\
\text { alanları, sanayi, tarım, } \\
\text { turizm, ulaşım, enerji } \\
\text { gibi sektörlere ilişkin } \\
\text { genel arazi kullanım } \\
\text { kararlarını } \\
\text { belirlemek,yerleşme ve } \\
\text { sektörler arasında } \\
\text { ilişkiler ile koruma- } \\
\text { kullanma dengesini } \\
\text { sağlamak, kıyı } \\
\text { alanlarının } \\
\text { korunması,imar } \\
\text { planlarında güüzergahı } \\
\text { netleşecek yolların genel } \\
\text { şeklini belirlenmesi }\end{array}$ & $\begin{array}{l}\text { Uygulama imar } \\
\text { planına esas } \\
\text { oluşturmak }\end{array}$ & $\begin{array}{c}\text { Yapılaşma ve } \\
\text { uygulamaya iliş̧kin } \\
\text { kararları, uygulama için } \\
\text { gerekli imar uygulama } \\
\text { programlarına esas } \\
\text { olacak uygulama } \\
\text { etaplarını ve diğer } \\
\text { bilgileri ayrıntıları ile } \\
\text { göstermek }\end{array}$ \\
\hline
\end{tabular}

İlgili kanun ve yönetmelikler incelendiğinde ana mekânsal planlama kademesi dışındaki planların varlığı da göze çarpmaktadır. Bu planlar özel alanlarda özel amaçlarla yapılan planlardır ve çevre düzeni planının veya imar planının yerini tutan mekânsal planlar şeklinde iki kategoride ele alınır. Tablo 3 'te özel planlar yerini tuttuğu ana kademe plan ile birlikte verilmiştir. Özel amaçlarla özel planların yapılabilmesi için plan bölgesi ilgili kurum tarafindan tespit edilmeli ve ana planlama hiyerarşisinden çıkarılmalıdır. Özel planları yapma, yaptırma ve onama yetkisi spesifik planlama amacına göre yerel idareler dışında konuyla ilgili bakanlık veya müdürlüklerdedir. Özel planların dışındaki tamamlayıcı planlar ise imar planı olan bölgelerde değişiklikler ile oluşan revizyon imar planı ve yeni yerleşim alanlarının kullanıma açılması için üretilen mevzi imar planlarıdır.

Tablo 3'te bahsi geçen planların hazırlanabilmesi için öncelikle bu alanların ilgili kurum tarafından ilan edilmesi ve planların ana kademe planlardan çıkarılması işlemleri gerçekleşmelidir. Bu işlemler gerçekleştirildikten sonra plan yapma ve yaptırma yetkisi olan kurum planları yapar ya da yaptırır. Söz konusu planların ana mekânsal planlama hiyerarşisinin dışında olması, üst kademe planlardan bağımsız olduğu anlamına gelmemektedir. Özel alanlarda yapılan özel planların uyması gereken şartlar hakkında üst ölçekli plan notlarında yönlendirmeler bulunmaktadır. 
Çalışmanın amacı doğrultusunda en önemli kısım, planların temsil ettiği HKS'lerin tespit edilmesidir. Bu nedenle çalışmada elde edilmek istenen ana çıktı planların ve plan notlarının içerdiği bilgilerin belirlenmesidir. Söz edilen bilgileri elde etmek amacıyla en küçük kapsamda bir il, bölge ve havza için yapılabilen çevre düzeni planı ile daha kapsamlı şekilde doğrudan parsel bazında bilgi içeren nazım ve uygulama imar planları incelenmiştir. İlgili planların pafta gösterimlerinden ve plan notlarından değindikleri konular ve ne gibi HKS'ler içerebildiği tespit edilmeye çalışılmıştır. İncelenen planlar, sadece kendi kapsadıkları alandaki bilgileri temsil ettiğinden ilgili kademedeki planın daha fazla ne gösterebileceğinin anlaşılması için ÇŞB’nin yayımladığı plan gösterimleri tabloları da incelenerek çalışma desteklenmiştir. İncelemeler sonucunda ÇDP, NIP ve UİP'lerin plan paftasında temsil ettikleri bilgiler ile plan notlarında değindikleri konular belirlenmiş, elde edilen çıktılar plan kademelerine göre plan paftası ve plan notları şeklinde Tablo 4'te sunulmuştur.

Elde edilen veriler incelendiğinde ÇDP'lerin plan paftalarında büyük alanların temsil edildiği ve sınıflandırıldığı görülmektedir. ÇDP'lerde bu sınıfların net bir şekilde kapsadığı alanın sınırları belirtilmemektedir. Alan sınıflarını; kentselkırsal yerleşme alanları, tarım alanları, teknoloji geliştirme alanları, depolama alanları, tarım alanları vb. oluşturmaktır. ÇDP'ler günümüzdeki kullanımların yanında gelecek için planlanan arazi kullanımlarını da içermektedir. Planlanan kullanımlarda kamu kurumlarının yatırım fikri değiştirmesi halinde planda değişikliğe gidilmektedir. Alan kullanım gösterimleri dışında ÇDP'ler önemli turizm noktalarını ve korunması gereken sit alanlarını da göstermektedir. ÇDP'lerin plan notları ise alt kademe planların yapılmasında nasıl bir yol izleneceği, temalarına göre bölgelerde çevre koruma adına nasıl tedbirler alınacağı ve özellikle tarım, sanayi, ticaret alanlarında yapılaşma koşullarının nasıl olması gerektiği hakkında kararlar içermektedir. Üst ölçekli bir plan kademesi olmasına rağmen ÇDP’lerin ilgili alanlarda inşaat alanı ve yapı geometrisi ile ilgili sınırlamalar içermesi hiyerarşi açısından önemlidir.

Tablo 3: Özel alanlarda ana mekânsal planların yerini alan planlar

\begin{tabular}{cc}
\hline \multicolumn{2}{c}{ Özel Amaçlı Planlar } \\
\hline Çevre Düzeni Planı Niteliğinde Olan Planlar & İmar Planı Niteliğinde Olan Planlar \\
\hline Her Tür ve ölçekte Koruma Alan Planları & Koruma Amaçı İmar Planı \\
\hline Kültür ve Turizm Koruma ve Gelişim Planı & Turizm Merkezi İmar Planı \\
\hline & Özel Çevre Koruma Bölgesi İmar Planı \\
\hline Köy Yerleşme Planı \\
\hline Organize Sanayi Bölgelerinde İmar Planları \\
\hline Teknoloji Geliştirme Bölgesinde İmar Planları \\
\hline Özel Orman Alanlarında İmar Planları \\
\hline Özelleştirme Alanlarında İmar Planları \\
\hline Toplu Konut Alanları İmar Planları \\
\hline Su Havzalarında İmar Planları \\
\hline Afet Riski Altındaki Alanlarda İmar Planları \\
\hline Tarım Alanlarında İmar Planları \\
\hline
\end{tabular}


Tablo 4: Mekânsal planların ve plan paftalarının içerdiği bilgi ve gösterimler

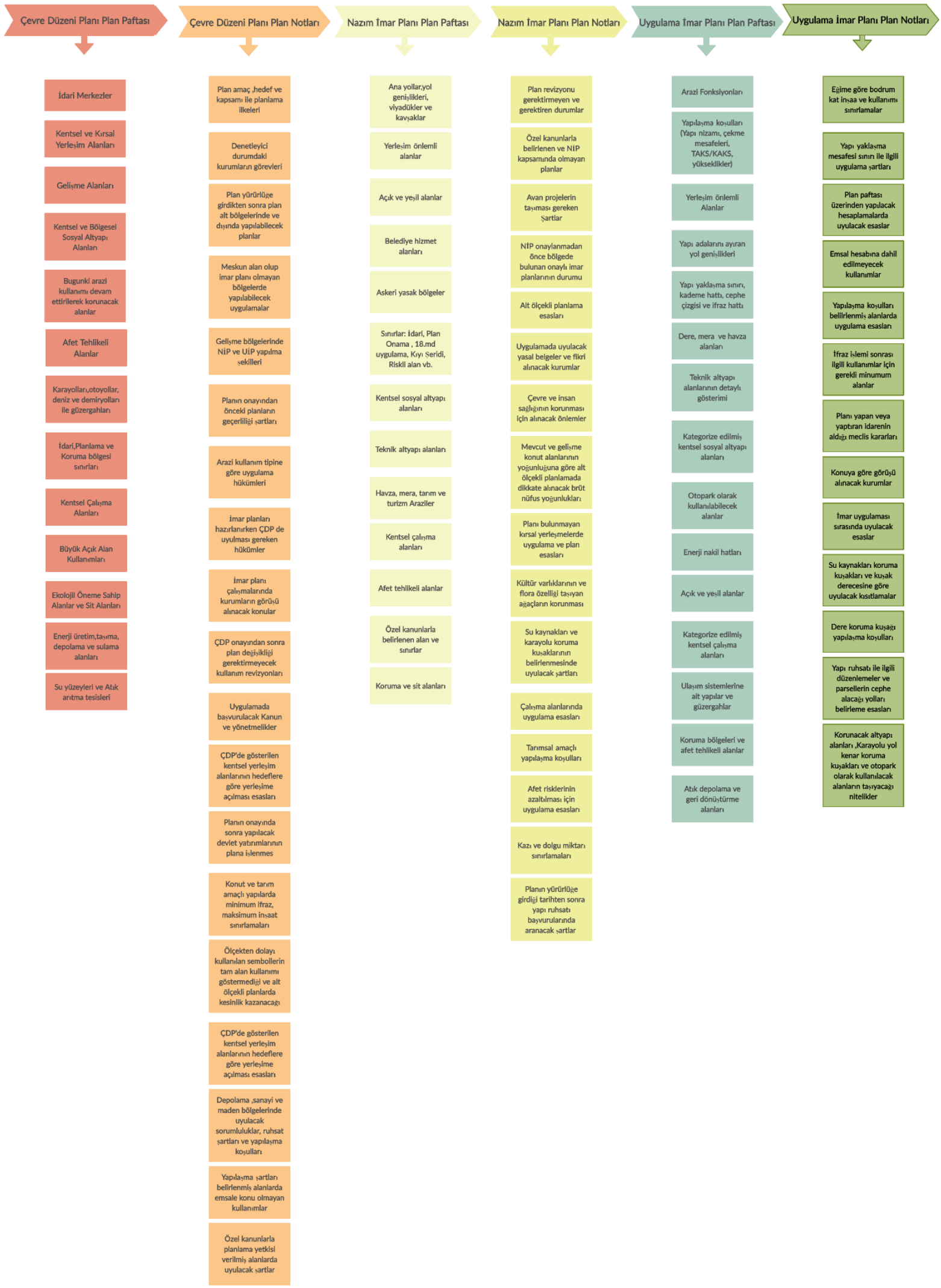

İmar planları mercek altına alındığında ise, imar planlarının ÇDP'lere göre daha fazla detay içerdiği ve uygulamaya dönük olduğu görülmektedir. Bu planlardan NIP pafta gösteriminde; yerleşim alanlarındaki sosyal, teknik, kültürel ve eğitim altyapılarına, bölgelerin yoğunluklarına, genel arazi kullanımlarına ve yerleşme kısıtlı alanlara yer verilmektedir. NiP plan notlarında ise UiP etapları hakkında uyulacak sorumluluklar, kazı-dolgu kısıtlamaları, koruma kuşaklarının oluşturulma 
şekilleri, kültür varlıklarının korunması vb. bilgiler sunulmuştur. UIP paftalarında NiP'lerde sunulan bilgilerin detaylandırılması ve parsel seviyesinde temsili sağlanmıştır. Bunun dışında önemli bir karar gösterimi olan parsellerde yapılaşma koşulları da UİP'lerde sunulmaktadır. Ayrıca UİP'leri diğer planlardan ayıran bir diğer özellikte sadece bu plan paftaları üzerinde ölçü alınıp hesap yapılabilmesidir. UIPP plan notlarında daha çok imar uygulaması ile ilgili uygulama şartları yer almaktadır. Ayrıca notlarda; eğime göre bodrum kat kazanımı, otopark olarak kullanılabilecek alanlar, emsal hesabına dahil edilecek kullanımlar, belediye meclis kararları, korunacak altyapı alanları ve ruhsat işlemleri ile ilgili bilgilere yer verilmiştir. Planlarda yer alabilecek HKS'ler sınırları belirli ve belli bir standarda oturtulmuşken plan notlarında yer alabilecek bilgiler ve HKS'ler geniş bir kapsamdadır ve herhangi bir standardı olmadığı görülmektedir. Bundan dolayı plan notlarında yer alan hak, kısıtlılık, sorumluluklar çeşitlidir ve esnek bir şekilde bir sınırlamaya maruz kalmadan genişletilebilir.

Çalışma neticesinde elde edilen bulgulardan olan plan hiyerarşisi bilgisi ile mekansal plan paketinin sınıfları oluşturularak aralarında kapsama, içerme, genelleştirme gibi ilişkiler kurulabilecektir. Diğer bir bulgu olan planların genel özellikleri ile oluşturulan sınıfların öznitelikleri ve veri tipleri oluşturulabilecektir. Özel amaçlarla özel bölgelerde yapılan planların bilgisi sayesinde de mekânsal planlamanın amacı öznitelik olarak sınıflara eklenebilecektir. Çalışma kapsamında son bulgu olan planların paftalarının ve plan notlarının içerdiği bilgiler ise planların içerdiği HKS kod listelerinin oluşturulmasında ve AI_HKS sınıfı ile ilişsi kurulmasında kullanılabilecektir.

\section{Sonuçlar ve Öneriler}

$\mathrm{Bu}$ çalışmada, arazide ve maliklerin mülkiyet haklarında plan aracıllğıyla oluşan HKS'lerin AİTM standardında temsilinin sağlanabilmesi için Türkiye mekânsal planlama sistemi incelenmiştir. İnceleme kapsamında kanunlar, yönetmelikler, ilgili tablolar, örnek planlar ve plan notları gözden geçirilmiştir. İncelemeler sonucunda farklı kademelerdeki mekânsal planların genel özellikleri ve ada, parsel bazında doğrudan etkili olacak HKS bilgileri içeren ÇDP ile imar planlarının içerikleri elde edilmiştir. Planların içerikleri incelendiğinde mekânsal planların haklar ve kısıtlamalarla birlikte birçok sorumluluk içerdiği görülmektedir. AİTM'nin mevcut halinde kaynağını aldığı tespit ve tescil işlemleri genelde hak ve kısıtlama sağlar. Mekânsal planların modele entegrasyonu birçok sorumluluğun da temsil edilmesini sağlayacaktır.

Geleneksel 2B kadastro arazi idaresi, kentsel kaynak ve arazi yönetiminde hala baskın bir rol oynasa da, 3B durumlarla ilgili kayıt için özel ihtiyaçlar, arazi yönetiminde gerçek zorlukları ortaya çıkarmaktadır (Guo vd., 2011). 3B kadastro ve tescil nesnelerinin görselleştirilmesi kapsamında mekânsal planlar önem arz etmektedir. Araziyi etkileyen hak ve kısıtlamaların tam olarak temsil edilmesi dünyada olduğu gibi Türkiye arazi yönetim sistemleri için de önemlidir. Bu gerekliliği sağlamak için araziye etki eden her HKS tespit edilmeli, belgelenmeli ve standart haline getirilmelidir. Gelecek çalışmalarda, bu çalışmanın devamı olarak bu çalışma bulguları kullanılarak planların ve plan notlarının içerdiği HKS'lerin kategorize edilmesi, tespit edilen kategorilere göre mekânsal planlama paketi, sınıfları, öznitelikler, kod listelerinin oluşturulması ve mekânsal planların AİTM Türkiye ülke profiline entegre edilmesi üzerine çalışmalar yapılması düşünülmektedir.

\section{Yazar Katkısı}

Okan Yılmaz: Tasarım, Literatür taraması, Veri toplama, Analiz ve yorumlama, Yazım. Mehmet Alkan: Fikir, Veri toplama, Analiz ve yorumlama, Denetleme, Makale değerlendirme. 


\section{Çıkar Çatışması Beyanı}

Yazarlar, bu çalışmada bilinen ilgili herhangi bir finansal veya finansal olmayan çıkar çatışması olmadığını beyan eder.

\section{Kaynaklar}

Aien, A., Rajabifard, A., Kalantari, M., \& Shojaei, D. (2015). Integrating legal and physical dimensions of urban environments. ISPRS international journal of geo-information, 4(3), 1442-1479.

Alattas, A., Zlatanova, S., Van Oosterom, P., Chatzinikolaou, E., Lemmen, C., \& Li, K. J. (2017). Supporting indoor navigation using access rights to spaces based on combined use of IndoorGML and LADM models. ISPRS international journal of geoinformation, 6(12), 384.

Alattas, A., Kalogianni, E., Alzahrani, T., Zlatanova, S., \& van Oosterom, P. (2021). Mapping private, common, and exclusive common spaces in buildings from BIM/IFC to LADM. A case study from Saudi Arabia. Land Use Policy, 104, 105355.

Alkan, M., \& Polat, Z. A. (2017). Design and development of LADM-based infrastructure for Turkey. Survey review, 49(356), 370-385.

Alkan, M., \& Polat, Z. A. (2018). Analysis of Studies on the Land Administration Domain Model in Turkey. 7th International FIG Workshop on the Land Administration Domain Model.

Atazadeh, B., Kalantari, M., Rajabifard, A., Ho, S., \& Ngo, T. (2017). Building information modelling for high-rise land administration. Transactions in GIS, 21(1), 91-113.

Atazadeh, B., Rajabifard, A., \& Kalantari, M. (2018). Connecting LADM and IFC standards-pathways towards an integrated legal-physical model. 7th International FIG Workshop on the Land Administration Domain Model.

Aydınoğlu, A. Ç., \& İnan, H. İ. (2014). Developing land registry and cadastre base data model for land management applications. FIG Congress 2014, 16-21.

Bydłosz, J., Bieda, A., \& Parzych, P. (2018). The implementation of spatial planning objects in a 3D cadastral model. ISPRS International Journal of Geo-Information, 7(4), 153.

Cheng, J., Turkstra, J., Peng, M., Du, N., \& Ho, P. (2006). Urban Land Administration and Planning in China: Opportunities and Constraints of Spatial Data Models. Land Use Policy 23(4):604-16.

Çağdaş, V., Kara, A., van Oosterom, P., Lemmen, C., Işıkdağ, Ü., Kathmann, R., \& Stubkjær, E. (2016). An initial design of ISO 19152: 2012 LADM based valuation and taxation data model. Isprs Journal of Photogrammetry and Remote Sensing, 4, 145-154.

Çete, M., \& İnan, H. İ. (2013). Kadastroda Modern Eğilimler ve Türkiye Kadastrosu. 14. Türkiye Harita Bilimsel ve Teknik Kurultayl.

Döner, F. (2010). Türk Kadastro Sistemi için Üç Boyutlu Yaklaşım (Doktora Tezi). Karadeniz Teknik Üniversitesi, Fen Bilimleri Enstitüsü, Trabzon, Türkiye.

Guo, R., Ying, S., Li, L., Luo, P., \& van Oosterom, P. (2011). A Multi-jurisdiction Case Study of 3D Cadastre in Shenzhen, China as Experiment using the LADM. 2nd International Workshop on 3D Cadastres.

Guo, R., Li, L., Ying, S., Luo, P., He, B., \& Jiang, R. (2013). Developing a 3D cadastre for the administration of urban land use: A case study of Shenzhen, China. Computers, Environment and Urban Systems, 40, 46-55.

Guo, R., Luo, F., Zhao, Z., He, B., Li, L., Luo, P., \& Ying, S. (2014). The applications and practices of 3D cadastre in Shenzhen. Proceedings of the 4th International Workshop on $3 D$ Cadastres.

Gürsoy Sürmeneli, H., \& Alkan, M. (2020). Towards standardisation of Turkish cadastral system using LADM with 3D cadastre. Survey Review, 1-16.

Indrajit, A., van Loenen, B., Ploeger, H., \& van Oosterom, P. (2020a). Developing a spatial planning information package in ISO 19152 land administration domain model. Land Use Policy, 98, 104111.

Indrajit, A., Jaya, V. E., van Loenen, B., Lemmen, C., van Oosterom, P., Ploeger, H., \& Theodore, R. (2020b). The Role of The Revised Land Administration Domain Model and Spatial Data Infrastructure In Improving Ease Of Doing Business In Indonesia. Proceeding of the 2020 World Bank Conference on Land and Poverty.

Indrajit, A., van Loenen, B., Jaya, V. E., Ploeger, H., Lemmen, C., \& van Oosterom, P. (2021). Implementation of the spatial plan information package for improving ease of doing business in Indonesian cities. Land Use Policy, 105, 105338. 
İnan, H. (2010). Arazi idare sisteminin tarım bileşeni olarak konumsal veri modeli geliştirilmesi (Doktora Tezi). Karadeniz Teknik Üniversitesi, Fen Bilimleri Enstitüsü, Trabzon, Türkiye.

İnan, H., \& Yomralooğlu, T. (2011). Arazi İdaresi İçin Konumsal Modelleme. Jeodezi ve Jeoinformasyon Dergisi, (104), 21-29.

Kalogianni, E., Janečka, K., Kalantari, M., Dimopoulou, E., Bydłosz, J., Radulović, A., Vučić, N., Sladić, D., Govedarica, M., Lemmen, C., \& van Oosterom, P. (2021). Methodology for the development of LADM country profiles. Land Use Policy, 105, 105380.

Lemmen, C. H. J., van Oosterom, P. J. M., Uitermark, H. T., Zevenbergen, J. A., \& Cooper, A. K. (2011). Interoperable domain models: The ISO land administration domain model LADM and its external classes. 28th Urban Data Management Symposium.

Lemmen, C. H. J., van Oosterom, P. J., Kara, A., Kalogianni, E., Shnaidman, A., Indrajit, A., \& Alattas, A. (2019). The scope of LADM revision is shaping-up. 8th Land Administration Domain Model Workshop.

Paasch, J. M., van Oosterom, P., Lemmen, C., \& Paulsson, J. (2015). Further modelling of LADM's rights, restrictions and responsibilities (RRRs). Land use policy, 49, 680-689.

Polat, Z. A., Alkan, M., \& Lemmen, C. H. J. (2020). A LADM-based temporal cadastral information system for modelling of easement rights-A case study of Turkey. Survey review, 52(370), 1-12.

Rajabifard, A., Atazadeh, B., Yip, K. M., Kalantari, M., Rahimipour Anaraki, M., Olfat, H., Badiee, F., Shojaei, D., Lim, C. K., \& Mohd Zain, M. A. (2019). Design and Implementation of a 3D National Digital Cadastral Database based on Land Administration Domain Model: Lessons Learned from a 3D Cadaster Project in Malaysia. 8th Land Administration Domain Model Workshop.

SFOTS (2015). The Cadastre of Public-law Restrictions on Landownership (PLR-cadastre). Swiss Federal Office of Topography swisstopo.

Steudler, D. (2014). CADASTRE 2014 and Beyond. Copenhagen, Denmark: International Federation of Surveyors (FIG)

Uitermark, H. T., van Oosterom, P. J. M., Zevenbergen, J. A., \& Lemmen, C. H. J. (2010). From LADM/STDM to a spatially enabled society: a vision for 2025. Land Governance-Moving towards' land information 2025: next steps-Annual Bank Conference On Land Policy and Administration. 